\title{
The Implementation of A No Smoking Area Policy at The Tomohon's DPRD Secretariat Office
}

\author{
Monika Alfa Paat, Itje Pangkey, Fitri Mamonto
}

Manado State University, Tandano, North Sulawesi, Indonesia

Email: monikapaat14@gmail.com, itjepangkey@unima.ac.id, fitrimamonto@unima.ac.id

\begin{tabular}{|c|c|}
\hline ARTICLE INFO & ABSTRACT \\
\hline $\begin{array}{l}\text { Received: 05-01-2022 } \\
\text { Revision: } 13-01-2022 \\
\text { Received : 18-01-2022 } \\
\text { Keywords: } \\
\text { Regulation } \\
\text { implementation; No } \\
\text { Smoiking Area (KTR); } \\
\text { Socialization }\end{array}$ & $\begin{array}{l}\text { This research aims to describe the implementation and the aspects } \\
\text { that hinder the No Smoking Area Policy at the Tomohon's DPRD } \\
\text { Secretariat Office. This research uses descriptive qualitative } \\
\text { method. The data in this study were obtained from interviews and } \\
\text { documentation. The informants in this study were the Head of the } \\
\text { Trial and Legislation Section, the Head of the Trial, Minutes and } \\
\text { Publications Sub-Section, the Head of the Equipment and } \\
\text { Household Sub-Division, as well as the staff of the Tomohon's } \\
\text { DPRD Secretariat Office. The results of the study show that the } \\
\text { implementation of the No Smoking Area policy at the Tomohon's } \\
\text { DPRD Secretariat Office has not been fully implemented properly. } \\
\text { The socialization has been carried out since the implementation of } \\
\text { the No Smoking Area policy. The readiness for implementation has } \\
\text { not fully demonstrated an attitude that supports the No Smoking } \\
\text { Area policy at the Tomohon City DPRD Secretariat Office. There are } \\
\text { still employees who do smoking activities not in the space provided. } \\
\text { The office head has not implemented strict sanctions related to the } \\
\text { Non-Smoking Area. }\end{array}$ \\
\hline
\end{tabular}

\section{Introduction}

Indonesia is one of the five largest tobacco-producing countries globally, which contributes to the production of 7.5 million tons of tobacco for global consumption each year. Dwini Handayani as Deputy Head of the Demographic Institute, Faculty of Business Economics, University of Indonesia (FEB-UI) explained the data on young smokers in Indonesia "The number of young smokers who range from 15-19 years old continues to increase from year to year. Every 1 in 5 children in Indonesia aged 13-15 years have smoked, and 1 in 3 children in Indonesia have tried smoking for the first time before turning 10 years old. One of the practical efforts made by the government to protect the entire community from being affected by other people's cigarette smoke is the implementation of a smoke-free area. Joint Regulation of the Minister of Health and the Minister of Home Affairs Number 188/MENKES/PB/I/2011 (RI, 2020).

Tobacco use has been shown to have negative effects on the majority of human bodily systems such as on the harmful consequences of smoking on diseases with high mortality rates, such as cancer and disorders of the cardiovascular and respiratory systems, with less focus on other bodily systems, such as the musculoskeletal system (Al-Bashaireh, 2018). Moreover, in Europe, smoking prohibitions in both public and private workplaces were effective in lowering workplace passive smoking. However, considering the ineffectiveness of smoking prohibitions un current smokers'

\footnotetext{
How To Cite: Paat, M. A., Itje Pangkey, Fitri Mamonto (2022) The Implementation of A No Smoking Area Policy at The Tomohon's DPRD Secretariat Office. Journal of Social Science. 3(1). https://doi.org/10.46799/jss.v3i1.285 
homes, better techniques for avoiding smoking indoors are required (Olivieri, 2019).

Regarding Guidelines for the Implementation of Non-Smoking Areas Article 1 point 1 states that Non-Smoking Areas, starting now abbreviated as $K T R$, are spaces or areas that are declared prohibited for smoking activities or for producing, selling, advertising, or producing tobacco products. Implementing the Non-Smoking Area or KTR is expected to be a place for the community to get clean and healthy air and avoid various risks that are detrimental to health and life (Wawointana, Mokat, Langkay, Mawitjere, \& Pangkey, 2019).

Tomohon in 2016 issued Tomohon's Regional Regulation Number 11 of 2016 concerning Non-Smoking Areas. Non-Smoking Areas as referred to in Article 4 paragraph (1) letter $f$ Non-Smoking Areas include workplaces, furthermore in Article 10 workplaces as referred to in Article 4 paragraph (1) letter $f$ include government offices, both civilian and TNI (army) and POLRI (police). In determining the NonSmoking Zone, both local governments, each leader and/or person in charge is obligated to disseminate information on Non-Smoking Areas, this is contained in Article 14 paragraph (1) Local governments are required to disseminate information on KTR to all levels of society, government and private agencies, as well as other agencies. in Tomohon City through various information dissemination and education activities, furthermore contained in Article 14 paragraph (2) letter d: every leader, and/or person in charge of a place that includes KTR is obliged to: create a room and/or a particular area for smoking in each area KTR.

The purpose of the Tomohon's Regional Regulation Number 11 of 2016 concerning Non-Smoking Areas is to provide adequate protection from the dangers of cigarette smoke for active smokers and passive smokers, provide a clean and healthy space and environment for people free from cigarette smoke, protect public health. In general, the adverse effects of smoking both directly and indirectly, reducing the number of smokers and prevent novice smokers.

Based on from the Central Bureau of Statistics of Tomohon, the percentage of the population aged 15 years and over who smokes and the average number of cigarettes smoked per week according to the highest educational characteristics, in 2017, do not attended school/ did not finish elementary school $30.77 \%$ average cigarettes Cigarettes smoked per week 66.41, Elementary School and equivalent $34.72 \%$ average cigarette smoked per week 99.29, Middle School and equivalent $28.95 \%$ - Average cigarette smoked per week 90, Senior High School and above $25.26 \%$ The average number of cigarettes smoked per week is 81.66 , with the overall percentage of the population aged 15 years and over who smoke in Tomohon is $28.34 \%$ with the number of cigarettes smoked per day an average of 85 cigarettes. Meanwhile, at the Tomohon's DPRD Secretariat office, the total number of existing $A S N$ and temporary employees is 50 , with 15 active smokers. All of them are male employees or \% of the total employees in the Tomohon's DPRD Secretariat office.

The Tomohon's DPRD Secretariat office has implemented a No Smoking Area. This can be seen from installing no smoking signs such as no smoking stickers in office spaces and the construction of 1 special booth for smoking and 1 gazebo outside the particular office building. Smoke. However, the No Smoking Area implementation is still not fully understood by the public, in this case, the employees at the Tomohon's DPRD Secretariat Office. It was found in the observations that there were still some employees who smoked in the office area. The data is strengthened by the fact that there are still cigarette butts in the room, a Non-Smoking Area. It is also found that cigarette ashtrays are still provided in several meeting rooms. So it can be seen that the efforts made by the government to issue regional regulations without smoking seem to 
have been ignored or not responded well by the people of Tomohon, especially active smokers who work as employees at the Tomohon's DPRD Secretariat Office (Subarsono, 2012). This needs to be a concern for the further affirmation of the Tomohon Regional Regulation number 11 of 2016 concerning Non-Smoking Areas.

Of some who are active smokers, some people do not know that a particular smoking area has been provided, some other do smoking activities in areas that are NonSmoking Areas but rarely receive warnings from fellow employees and leaders so this activity still continue that should not be repeated. From the description, researchers are interested in examining how the implementation of the No Smoking Area Policy at the Secretariat Office of the Tomohon Regional People's Representative Council (DPRD).

\section{Problem Focus}

Implementation of the No-Smoking Area Policy at the Secretariat Office of the Tomohon's Regional House of Representatives (DPRD).

\section{Problem Formulation}

How is the No Smoking Area Policy (KTR) implemented at the Tomohon's DPRD Secretariat Office?

\section{Research Purposes}

To describe and analyze how the Implementation of the No Smoking Area Policy at the Tomohon's DPRD Secretariat Office.

\section{Implementation Concept}

The implementation means to implement. Implementation is the provision of means to carry out something that has an impact or effect (Oktasari, 2015).

\section{Public Policy Concept}

According to Anderson (1969) (in Agustino, 2016) the definition of public policy is a series of activities that have a specific purpose/objective that is followed or carried out by an actor or group of actors related to a problem or a matter of concern. Chandler and
Plano (1988) (in Dunn, 2003) state that public policy is also defined as the strategic use of existing resources to solve public or government problems. Carl Friedrich also revealed that public policy is a proposed direction of action or a policy proposed by a person, group, or government to overcome an obstacle or take advantage of an opportunity in a particular environment to achieve a goal or realize a goal (Wayne, 2006).

\section{Policy Implementation Concept}

The term implementation in the Big Indonesian Dictionary (KBBI) is usually associated with an activity carried out to achieve specific goals. "The concept of implementation comes from English, namely to implement (implement) means to provide the means for carrying out (providing the means to carry out something), to give practical effect to (cause an impact or effect on something). This understanding means that to implement something, it must be accompanied by supporting facilities that will later impact or affect something (Wahab, 2012).

\section{Determinants of Policy Implementation}

Policies made by the government are not only intended and implemented for the internal government but are also intended and must be implemented by all communities in their environment. According to (Agustino, 2016), the determinants of policy implementation are as follows:

1. Community members' respect for government authorities and decisions

2. Awareness to accept the policy

3. Whether or not there are legal sanctions

4. Personal or group interests

5. Contrary to existing values

6. Membership of a person or group of people in an organization

7. The existence of selective compliance

8. Time

9. Socialization

10. Coordination between Inter-institutional or inter-organizational coordination. 
George C. Edward III's policy implementation model (1980) in (Agustino, 2016) proposes four factors or variables that influence the success or failure of policy implementation. The four variables or factors in question include:

1. Variable Communication.

2. Variable Resources, such as human resources, budget resources, equipment resources (facility), and information resources and authority.

3. Varible Dispotition.

4. Variable Bureaucratic Structure.

\section{No Smoking Area Concept}

Non-Smoking Area is a room or area that is declared prohibited for smoking activities or activities to produce, sell, advertise, and/or promote tobacco products (Kemenkes RI, 2011: 14). The Government of the Republic of Indonesia has regulated a policy of prohibiting smoking through NonSmoking Areas (KTR) which is outlined in Law number 36 of 2009 and Joint Decree of the Minister of Health and Minister of Home Affairs Number 188/Menkes/PB/I/2011 and Government Regulation Number 109 of 2013 (Indonesia, 2009).

Based on those regulations in Tomohon, Regional Regulation Number 11 of 2016 concerning Non-Smoking Areas has been applied, which is also one of the factors, namely the government sees and is aware of the many dangers or negative impacts caused by cigarettes, whether people who are active smokers as well as people who are passive smokers only inhale the smoke released by the smoker.

In the Joint Regulation of the Ministry of Health and the Ministry of Home Affairs NUMBER 188/MENKES/PB/I/2011 and Number 7 of 2011 concerning Guidelines for the Implementation of Non-Smoking Areas Chapter II Scope of KTR Article (3) paragraph (1), several areas which are designated as non-smoking areas have been determined. No Smoking, in the Tomohon City Regional Regulation number 11 of 2016 concerning Non-Smoking Areas article 4, several areas are designated as non-smoking areas, which are then described in the following articles, there are:

1. Health Service Facilities

2. Place for the Teaching and Learning Process
3. Where Children Play
4. Places of Worship
5. Public Transportation
6. Workplace
7. Public Places
8. Other designated place.

Obligations and prohibitions on nonsmoking areas are regulated in Chapter IV, Rights, Obligations and Prohibitions. The obligation as referred to in article (14) The local government is obligated to disseminate information on KTR to all levels of society, government and private agencies, and other agencies in Tomohon City through various means of disseminating information and education, carrying out internal control at places and/or locations be his responsibility. Prohibiting, giving warnings and warnings to everyone who smokes in KTR. Placing signs and announcements about the prohibition of harvesting at KTR places. Create a room and/or area for smoking in each KTR area. While the particular room for smoking referred to here is an open room that is in direct contact with the outside air so that the air can circulate properly. A closed room with air circulation is equipped with an ashtray or a cigarette butt disposal area.

In addition, A case in South Korea concerning No Smoking Area shows that when comparing subjects with a lower socioeconomic status and those who were exposed to public anti-smoking policies to those with a higher socioeconomic status and those who were not exposed to such policies, smoking reduction was significantly higher in those with a lower socioeconomic status and those who were not exposed to such policies (Han, 2019).

Huriah and Rahman (2020) looked into the study of a no-smoking area, according to 
the findings, a Center for Public Health Services must follow the strictest laws and provide specialized training in the prevention of smoking behavior in health workers in order to achieve specific knowledge and responsibility for smoking prevention. As a result, the current study differs from this one in that it examines a no-smoking area in a government workplace.

\section{Method}

\section{Research Approach}

Creswell, J.W. (in Sugiyono, 2013) says that research guided by the qualitative paradigm is defined as: "A research process to understand human or social problems by creating a comprehensive and complex picture, presented in words, reporting detailed views obtained from the sources of information, and carried out in a natural setting.

This research was conducted with a qualitative approach because qualitative research emphasizes the process of searching for meaning, revealing meaning, behind the phenomena that arise in research, with the aim that the problems to be studied are more comprehensive, in-depth, natural, and as they are and without much interference from the public and researchers to the facts that emerged.

\section{Research Focus and Focus Description}

In this study, the method used is a qualitative research method. Researchers are interested in conducting qualitative research because they want to explore and find details of the problem regarding the phenomenon of the Implementation of the No Smoking Area Policy at the Secretariat Office of the Tomohon's DPRD.

One of the critical factors in research is to determine the research focus. The need for the focus of this research is to limit the problem in research so that the object to be studied is not comprehensive and too broad. This research is focused on (1) the implementation of a No Smoking Area Policy at the Tomohon's DPRD Secretariat Office:
Implementation of a No Smoking Area policy, in this case, is related to policy socialization. The public means employees who are active smokers. Regarding this matter, the policy socialization has been carried out. However, the socialization activities carried out only to the urban village community do not include offices or agencies and services within the Tomohon government, including the Secretariat of the Tomohon DPRD.

Inhibiting Factors in the Implementation of a No Smoking Area Policy. In the results of field observations, it can be concluded that two factors hinder the implementation of the No Smoking Area Policy at the Tomohon's DPRD Secretariat Office, including Availability of particular smoking areas and sanctions.

\section{Results And Discussion \\ Overview of Research Locations}

Tomohon is one of the cities in North Sulawesi Province, Indonesia. Prior to 2003, Tomohon was a sub-district in Minahasa Regency. In its development, Tomohon has made much progress, there are aspirations from its citizens to improve the status of Tomohon into a city (Mamonto, Langkai, \& Mowilos, 2020). Tomohon became an autonomous region (city) with the ratification of Law Number 10 of 2003 concerning the Establishment of South Minahasa Regency and Tomohon City in North Sulawesi Province by the Indonesian Parliament. However, the inauguration was only on August 4, 2003. The population of this city was estimated at 106,917 people in 2017 and 2019.

\section{Research result}

This research is qualitative. The Researcher directly to the field using research approaches to examine more deeply how the No Smoking Area Policy (KTR), especially in Tomohon's DPRD Secretariat Office, and the inhibiting factors for the implementation of the No Smoking Policy in Tomohon's DPRD Secretariat Office was not carried out properly, thus researchers got some findings and facts in the field. 
The researchers used interview techniques, field observations, and documentation of the data obtained from the field (actual data), namely the results of interviews with the selection of informants in this study, both superiors and employees at the Tomohon's DPRD Secretariat Office. 5 informants, including (SP) Head of the Trial and Legislation Section, (IN) Head of the Trial, Minutes and Publications Sub Division, (MK) Head of the Equipment and Household Sub Division, (VM) Civil Servant of the Facilitation Sub Division, ( HM) Staff of the Trial Sub-Division Contract Personnel. The data from the interviews of researchers with informants are as follows.

1) Interview results with the supervisor at Tomohon's DPRD Secretariat Office

Based on an interview with SP:

"The application of a Non-Smoking Area in Tomohon City, especially in public spaces such as offices, especially in the Tomohon City DPRD Secretariat Office, has been carried out and can be seen by making special booths for smoking and installing no smoking stickers in work rooms" ( SP)

SP further states:

"To assess the level of application of this Non-Smoking Area is good or not, this is certainly relative because at certain times there are still some violations, especially for smokers, because there are certain places that should be sterile from cigarette smoke. There is also no special sanction issued from the office head, only in the form of verbal sanctions or reprimands. But again, what is needed is more on the consciousness of each of us" (SP)

Based on an interview with IN:

"Regarding the Non-Smoking Area, I know that there is a regional regulation, but to clarify the number and year of the regional regulation, I have forgotten, and for the implementation in this office, I think it is still not optimal because there are still smoking in any place because there are no strict sanctions given to violators. in this office. In fact, what I see is that most guests or newcomers violate the rules and are ignorant of the rules, such as a room with a no smoking sticker on it, but instead they are doing smoking activities there" (IN)

Furthermore, according to IN:

"Yes, as far as I know, socialization is being carried out, but only to the general public in the kelurahan, and the socialization of this regional regulation is carried out by legislative members to the community in the electoral district of each member of the legislature. But special socialization in each official office or agency, etc. as far as I know, does not yet exist and maybe this can be added regarding socialization in official offices and agencies, etc., and pamphlets advertising the prohibition of smoking can be added again to remind us again" ( IN)

Based on an interview with MK:

"I know that the implementation of KTR in this office has been implemented, because the office has provided special smoking areas such as gazebos outside the office, smoking booths are on the ground floor of the office and smoking ban stickers in each workspace for both the head and employees. For special rules, there may not be any but they have been notified and it is only up to someone who understands to apply them, and the level of awareness in my opinion should be increased again" (MK)

Furthermore, MK conveyed:

"Perhaps for us smokers, we ourselves have considered not prohibiting but other people's assessment of us still violates it. So maybe this should be socialized more 
to reduce the level of smokers in this office and of course it will also have a good impact on Tomohon" (MK)

2) Interview results with employees and contract staff of Tomohon's DPRD Secretariat Office

Based on an interview with $\mathrm{HM}$ :

"I know that the KTR regional regulation has special sanctions and a special supervisory team, but the application in this office in terms of giving special sanctions is not there so maybe the level of supervision is less because there are no special sanctions, only verbal warnings when I see people smoking carelessly, especially in my office, and I assessed that before this regulation was implemented in the office and after it was implemented the results were almost the same, not much real change" (HM)

Based on the interview with VM:

"I know about this KTR, but from the local regulations enacted in this office, the level of supervision has not yet been implemented, only a few verbal warnings have been given. Of course, after the KTR regional regulation is made, it should not only be disseminated at the community level, but also apply the sanctions contained in the regional regulation so that everything in the regional regulation functions and all people who smoke know to put themselves in place" (VM)

VM further added:

"For a special smoking area, I see that it already exists but I'm not sure whether the space provided is a special place for smokers because only it is in the form of a gazebo and there is no sign "special place for smoking", there is also on the ground floor of the parking lot I see there is a smoking booth but it is very dirty and has not been used, maybe because the distance is a bit hidden or maybe there is no signpost to the designated smoking area" (VM).

\section{Discussion result}

\section{Socialization of No Smoking Area Policy}

Communication is the activity of delivering messages from one person to another to influence the behavior and actions of that person either directly or indirectly. According to (Handoko, 2002) Communication is the process of transferring understanding in the form, ideas, information from one person to another. Furthermore, in (Nugroho 2017), Communication relates to how policies are communicated to organizations and/or the public and the attitudes and responses of the parties involved.

Based on interviews results, employees already know information about the No Smoking Area, which is applied at Tomohon's DPRD Secretariat Office. This is supported by the provision of booths or special rooms for smoking and the installation of no smoking stickers in almost all office rooms. However, according to one informant, he still often sees cigarette smoke in the Non-Smoking Area. Thus it can be said that the level of awareness of the employees is still low. The employees also think that the socialization is still lacking, there are even employees who admit that they often reprimand their workmates who smoking in areas that have been installed with no smoking stickers, even there are still several office rooms that provide cigarette ashtrays.

Based on the results of the study, it was found that the Perda on the No-Smoking Area in Tomohon had been made. However, the socialization was only limited to the community in the village and no socialization in official offices and agencies in Tomohon. From the facts through interviews, it can be said that the implementation of the No Smoking Area Policy will not run as expected if it is not communicated. In this case, it is not properly socialized or lacks socialization.

The researcher assumes that implementing the No Smoking Area Policy at Tomohon's DPRD Secretariat Office can run 
optimally if the socialization could covering existing office areas, agencies and agencies and of course carried out sustainably. The goal is that the public, including employees within Tomohon government, especially at Tomohon's DPRD Secretariat Office, which is the research focus, can understand the things regulated in Regional Regulation Number 11 of 2016 concerning the Smoking-Free Area.

\section{Availability of designated smoking areas}

Determination of a smoke-free area is one of the safeguards for addictive substances not to interfere and endanger the health of individuals, families, communities, and the environment. Further regulation regarding the handling of addictive substances, especially cigarettes, refers to Government Regulation Number 109 of 2012 concerning the Safety of Materials Containing Addictive Substances in the Form of Tobacco Products for Health. According to Article 50 paragraph (4) and Article 51 paragraph (1) of PP 109/2012, it is stated: Article 50 paragraph (4), the leader or person in charge of the place as referred to in paragraph (1) is obliged to implement a No Smoking Area. Article 51 paragraph (1), 1 . The non-smoking area as referred to in Article 50 letter $f$ (workplace) and letter $\mathrm{g}$ (public place and other designated places) provides a special place for smoking, 2. As referred to in paragraph (1) (1), the particular smoking area must be an open space in direct contact with the outside air. What is meant by "open space" is a room where one side has no walls or roof so that cigarette smoke can be released directly into the air. In line with the above regulations, in the Joint Regulation of the Minister of Health and the Minister of Home Affairs Number 188/MENKES/PB/I/2017; Number 7 of 2017 concerning Guidelines for the Implementation of Non-Smoking Areas, workplaces are included in Non-Smoking Areas, and the head/ person in charge of workplaces is required to establish and implement a NoSmoking Area. The workplace or KTR as intended, can provide a special place for smoking which must meet the following requirements: $a$. is an open space or space that is in direct contact with outside air so that air can circulate properly; b. Separate from building/wrought/main room and other spaces used for activities; c. far from entrances and exits; and D. far away from where people pass by.

Based on the research results, the NonSmoking Area Policy at the secretariat of Tomohon's DPRD has been implemented, with the provision of unique booths for smoking and special open spaces for smoking. However, the application is not optimal, as seen from observations and interviews conducted by researchers when they go directly to the research location. There are 2 designated smoking areas with two different models, one is a cubicle (closed room) which is located on the ground floor near the office parking lot, but according to the informant's admission, there are no signposts or descriptions of a particular smoking area so that it confuses employees for the function of the booth. The other is a gazebo with an open model (open space), which is also not attached with a particular smoking area description make it rarely used.

Based on the findings, in terms of the availability of designated smoking areas, the office has either provided or facilitated, the researcher assumes that the primary function of booths and open spaces in the form of a gazebo for smoking will be adequately and optimally used if it is equipped with a signboard that reads a designated smoking area. Thus employees who do smoking can smoke in the space provided and do not disturb other employees who are not smokers.

\section{Sanctions}

Sanctions are a measure of punishment imposed by a particular state or group due to a violation committed by a person or group. Sanctions are defined as, dependents, actions, penalties to force people to comply with agreements or statutory provisions. 
According to the Big Indonesian Dictionary, sanctions are punitive actions to force someone to obey the rules or obey the law. Sanctions give unwanted (painful) results to minimize unwanted behavior.

To implement the No Smoking Area Policy at Tomohon's DPRD Secretariat Office to run well, the head of the office or office secretary needs to carry out supervision by providing sanctions according to the rules that apply to violators. In the Tomohon Regional Regulation number 11 of 2016 concerning "no smoking areas," Article 23 paragraphs (1) and (2) which reads; 1 . Any person and/or entity violating the provisions of Article 15 and Article 16 paragraph (2), and/or Article 17 shall be sentenced to a maximum imprisonment of 3 (three) months and/or a maximum fine of Rp. 500,000.00 (five hundred thousand rupiahs) for individuals and a maximum Rp. 10,000,000, for entities. 2. As mentioned in paragraph (1), the criminal act is a violation.

It has been clearly explained that those who violate this provision can be subject to criminal acts and fines. However, from the interviews, Tomohon's DPRD Secretariat Office does not even have clear sanctions related to violations of this provision. Thus many of employees smoking not in the designated places. The government, in this case, the head of Tomohon's DPRD Secretariat Office, must realize how vital supervision and control is in this case, giving strict sanctions for policy violators. As previously mentioned, no matter how good the government makes the policy, it will not be easy to implement it properly if it is not supported by good performance.

\section{Conclusion}

Implementation of the No-Smoking Area Policy at Tomohon Regional Representative Council Secretariat Office.

The No Smoking Area Policy has been implemented at Tomohon DPRD Secretariat Office. However, in its implementation, it is not yet good, as can be seen from the research conducted by researchers that show several factors in implementing this policy. The implementation of the No Smoking Area Policy at Tomohon DPRD Secretariat Office is not implemented correctly and has not been running effectively due to several reasons in the following paragraph.

Tomohon's DPRD Secretariat Office has not received direct socialization. The socialization was limited to the village community, thus employees lack information related to the Non-Smoking Area.

Availability of the place or smoking booths are not equipped with a "special smoking area" signboard thus there are still many who smoke in any office room.

In this case, the head of Tomohon's DPRD Secretariat Office, does not stipulate special sanctions or strict sanctions for violators. Only a verbal warning is given so that smoking activities in any place continue to be carried out repeatedly.

\section{Suggestion}

Based on the conclusions, the researchers suggest:

Socialization of activities related to No Smoking

Areas needs to be disseminated to offices and agencies and carried out sustainably. Thus information related to NonSmoking Areas can be understood by smokers and does not harm other people who do not smoke.

The availability of a particular smoking area at Tomohon's DPRD Secretariat Office needs to be clarified its use and function again so that it is not used for other activities.

There is a need for strict sanctions from the official head, the secretary of the board. The head must use the authority in terms of supervision and control of violators of this policy to have a deterrent effect and increase awareness about the dangers of smoking and the dangers of smoking in any place. 


\section{References}

Agustino, Leo. (2016). Dasar-dasar kebijakan publik (Edisi Revisi). Bandung: Alfabeta. Google Scholar

Al-Bashaireh, A. M., Haddad, L. G., Weaver, M., Kelly, D. L., Chengguo, X., \& Yoon, S. (2018). The effect of tobacco smoking on musculoskeletal health: a systematic review. Journal of environmental and public health, 2018. Google Scholar

Dunn, William N. (2003). Pengantar analisis kebijakan publik. Google Scholar

Han, M. A. (2019). The price of tobacco and its effects on smoking behaviors in Korea: The 2015 Korea Community Health Survey. Preventive medicine, 120, 71-77. Google Scholar

Huriah, T., Rohman,. A. (2020). Smoking behaviour on health workers in Indonesia: A phenomenological study. Advance in Health Sciences Research, 33 Google Scholar

Indonesia, Republik. (2009). Undang-undang Republik Indonesia nomor 36 tahun 2009 tentang Kesehatan. Jakarta Republik Indonesia. Google Scholar

Mamonto, Fitri H., Langkai, Jeane Elisabet, \& Mowilos, Rebecca C. (2020). Implementasi Kebijakan Pakta Integritas di KPU Kabupaten Minahasa. Jurnal Kajian Kebijakan Dan IImu Administrasi Negara (JURNAL ADMINISTRO), 1(2). Google Scholar

Oktasari. (2015). Implementasi Kebijakan dan
Politik. Jakarta: Grasindo.

Olivieri, M., Murgia, N., Carsin, A. E., Heinrich, J., Benke, G., Bono, R., ... \& Verlato, G. (2019). Effects of smoking bans on passive smoking exposure at work and at home. The European Community respiratory health survey. Indoor air, 29(4), 670-679. Google Scholar

RI, Kemenkes. (2020). Tetap Produktif, Cegah, dan Atasi Diabetes Mellitus. Pusat Data Dan Informasi Kementrian Kesehatan RI. Google Scholar

Subarsono, A. G. (2012). Analisis kebijakan publik: konsep, teori dan aplikasi. Google Scholar

Sugiyono, Dr. (2013). Metode penelitian pendidikan pendekatan kuantitatif, kualitatif dan R\&D. Google Scholar

Wahab, Abdul Solichin. (2012). Analisis kebijaksanaan dari formulasi implementasi kebijakan negara. Edisi Kedua. Jakarta: PT. Bumi Aksara. Google Scholar

Wawointana, Thelma, Mokat, Jetty, Langkay, Jeane, Mawitjere, Willem, \& Pangkey, Itje. (2019). The Optimalization of Village Community Function in Accepting and Distributing Community Aspirations in Kemelembuais Village. Google Scholar

Wayne, Parsons. (2006). Public Policy pengantar teori dan praktik analisis kebijakan. Jakarta: Kencana. Google Scholar

\section{Copyright holder :}

Monika Alfa Paat, Itje Pangkey, Fitri Mamonto (2022)

First publication right :

Journal of Social Science

\section{This article is licensed under:}

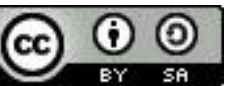

